\title{
ASPEK HUKUM BAHAYA PLASTIK TERHADAP KESEHATAN DAN LINGKUNGAN SERTA SOLUSINYA
}

\author{
Oleh:
}

\author{
Yusma Dewi ${ }^{1}$, Trisno Raharjo ${ }^{2}$ \\ Fakultas Hukum, Universitas Muhammadiyah Yogyakarta \\ E-mail: yusma_dewi@yahoo.com, trisnoraharjo@umy.ac.id
}

\begin{abstract}
Abstrak
Tujuan dari penelitian ini untuk mengetahui dan menganalisis aspek hukum bahaya plastik terhadap kesehatan dan lingkungan serta solusinya. Sejalan dengan permasalahan penelitian ini, maka jenis penelitian hukum yang digunakan bersifat penelitian hukum normatif dengan pendekatan perundang-undangan dan pendekatan kasus. Penelitian ini akan menjadikan pengelolaan sampah di Kabupaten Sleman sebagai model. Hasil penelitian ini menunjukkan bahwa (1) Undang-undang Nomor 18 Tahun 2008 tentang Pengelolaan Sampah tidak secara jelas mengatur mengenai sampah plastik dan larangan untuk menghasilkan sampah plastik. Oleh karena itu Undang-undang Nomor 18 Tahun 2008 tentang Pengelolaan Sampah belum dapat mencegah penggunaan plastik yang dapat menimbulkan sampah plastik yang berbahaya bagi manusia dan lingkungan; (2) Sampai saat ini belum ada peraturan perundang-undangan yang melarang penggunaan plastik yang membahayakan bagi kesehatan manusia dan lingkungan; dan (3) Solusi belum diaturnya larangan penggunaan plastik yang membahayakan kesehatan dan lingkungan maka sampah plastik bisa digunakan sebagai bahan untuk membuat kerajinan seperti aneka jenis tas, dompet, topi tempat koran, map, dan sebagainya seperti yang telah dilakukan oleh masyarakat Desa Sukunan, Kabupaten Sleman selama ini.
\end{abstract}

Kata kunci: Sampah, Plastik, Bahaya, Kesehatan, Lingkungan

\section{A. PENDAHULUAN}

Undang-undang Nomor 18 Tahun 2008 tentang Pengelolaan Sampah (selanjutnya disebut Undang-undang Sampah) menggolongkan sampah terdiri atas (a) sampah rumah tangga; (b) sampah sejenis sampah rumah tangga; dan (c) sampah spesifik. Sampah rumah tangga berasal dari kegiatan sehari-hari dalam rumah tangga, tidak termasuk tinja dan sampah spesifik. Sampah spesifik meliputi: (a) sampah yang mengandung bahan berbahaya dan beracun; (b) sampah yang mengandung limbah bahan berbahaya dan beracun; (c) sampah yang timbul akibat bencana; (d) puing bongkaran bangunan; (e) sampah yang

\footnotetext{
1 Penulis adalah Mahasiswa Magister IImu Hukum, Pascasarjana Universitas Muhammadiyah Yogyakarta.

2 Penulis adalah Dosen Magister IImu Hukum Pascasarjana Universitas Muhammadiyah Yogyakarta.
} 
secara teknologi belum dapat diolah; dan/atau (f) sampah yang timbul secara tidak periodik (Pasal 2 ayat (1) sampai dengan ayat (4) Undang-undang Sampah). Undang-undang Sampah tidak mengatur pengelolaan sampah berdasarkan sifatnya yang mudah diurai atau tidak terurai, bahkan dalam Undang-undang Sampah tersebut tidak ditemukan kata "sampah plastik".

Demikian juga Peraturan Pemerintah Nomor 81 Tahun 2012 tentang Pengelolaan Sampah Rumah Tangga dan Sampah Sejenis Sampah Rumah Tangga (selanjutnya disebut PP Sampah) juga tidak mengatur mengenai sampah plastik. Kata "plastik" ditemukan dalam penjelasan Pasal 11 PP Sampah dalam kaitannya dengan contoh implementasi pembatasan timbulan sampah antara lain: penggunaan barang dan/atau kemasan yang dapat didaur ulang dan mudah terurai oleh proses alam; membatasi penggunaan kantong plastik; dan/atau menghindari penggunaan barang dan/atau kemasan sekali pakai. Berdasarkan kondisi ini, dapat dikatakan baik Undang-undang Sampah maupun PP Sampah belum mengatur secara spesifik mengenai sampah plastik.

Jenis sampah yang paling potensial merusak lingkungan adalah jenis sampah anorganik, khususnya sampah plastik. Hal ini dikarenakan sampah jenis ini tidak dapat mengalami pembusukan secara alami sebagaimana sampah organik sehingga materi ini akan terus terkumpul selama beribu tahun di tanah tanpa adanya proses penguraian oleh bakteri dekomposer. Selain itu, hal ini juga disebabkan budaya masa kini yang serba instan dimana penggunaan materi berbahan plastik, dari sektor rumah tangga (konsumen) dan sektor industri (pelaku usaha), semakin meningkat yang pada akhirnya semakin banyak pula sampah plastik yang sulit terurai.

Sebagai gambaran banyaknya sampah plastik yang mendominasi sampah pada umumnya, data sampah di Kabupaten Sleman dari tahun 2013 sampai tahun 2015 dapat dikemukakan sebagai berikut.

Tabel 1. Data Sampah di Kabupaten Sleman dari Tahun 2013 - 2015

\begin{tabular}{ccccc}
\hline Tahun & $\begin{array}{c}\text { Jumlah } \\
\text { Sampah (Ton) }\end{array}$ & $\begin{array}{c}\text { Jumlah Sampah } \\
\text { Plastik (Ton) }\end{array}$ & $\begin{array}{c}\text { \% } \\
\text { Sampah } \\
\text { Plastik }\end{array}$ & $\begin{array}{c}\% \\
\text { Peningkatan }\end{array}$ \\
\hline 2013 & $47.186,81$ & $18.487,79$ & $39,18 \%$ & - \\
2014 & $59.462,77$ & $28.078,32$ & $47,22 \%$ & $+8,04 \%$ \\
2015 & $79.293,91$ & $47.489,12$ & $59,89 \%$ & $+12,67 \%$ \\
\hline
\end{tabular}




\section{Sumber: Pemerintah Kabupaten Sleman ${ }^{3}$}

Berdasarkan data tersebut di atas, terlihat bahwa persentase sampah plastik di Kabupaten Sleman terus meningkat setiap tahunnya. Pada tahun 2013 besarnya 39,18\% meningkat menjadi $47,22 \%$ di tahun 2014 atau meningkat sebesar 8,04\%. Demikian juga dari tahun 2014 yang semula 47,22\% meningkat menjadi $59,89 \%$ atau meningkat sebesar $12,67 \%$. Besarnya persentase sampah plastik di Kabupaten Sleman ini, bukan tidak mungkin terjadi juga di daerah lain di seluruh Indonesia.

Plastik adalah salah satu bahan yang dapat ditemui di hampir setiap barang. Mulai dari botol minum, alat makanan (sendok, garpu, wadah, gelas), kantong pembungkus/kresek, TV, kulkas, pipa pralon, plastik laminating, gigi palsu, sikat gigi, compact disk (CD), kutex (cat kuku), mainan anak-anak, mesin, alat-alat militer hingga pestisida. Menurut penelitian, penggunaan plastik yang tidak sesuai persyaratan akan menimbulkan berbagai gangguan kesehatan, karena dapat mengakibatkan pemicu kanker dan kerusakan jaringan pada tubuh manusia (karsinogenik). Selain itu plastik pada umumnya sulit untuk didegradasikan (diuraikan) oleh mikro organisme. Berbagai penelitian telah menghubungkan Bisphenol-A dengan dosis rendah dengan beberapa dampak terhadap kesehatan, seperti meningkatkan kadar prostat, penurunan kandungan hormon testoteron, memungkinkan terjadinya kanker payudara, sel prostat menjadi lebih sensitif terhadap hormon dan kanker, dan membuat seseorang menjadi hiperaktif. ${ }^{4}$

Sampah plastik dapat bertahan hingga bertahun-tahun sehingga menyebabkan pencemaran terhadap lingkungan. Sampah plastik tidaklah bijak jika dibakar karena akan menghasilkan gas yang akan mencemari udara dan membahayakan pernafasan manusia, dan jika sampah plastik ditimbun dalam tanah maka akan mencemari tanah, air tanah. Plastik sendiri dikonsumsi sekitar 100 juta ton/tahun di seluruh dunia. Satu tes membuktikan 95\% orang pernah memakai barang mengandung Bisphenol-A. Oleh karena itu pemakaian plastik yang jumlahnya sangat besar tentunya akan berdampak siqnifikan terhadap kesehatan manusia dan lingkungan karena plastik mempunyai sifat sulit

3 Bappeda Kabupaten Sleman, 2016, Profil Sanitasi Kabupaten Sleman, 2015. Pemerintah Kabupaten Sleman, Sleman, hIm. 19-22.

4 Nurhenu Karuniastut, 2011, Bahaya Plastik, Jurnal Forum Teknologi, Vol. 03, No.1, hlm. 6. 
terdegradasi (non-biodegradable), plastik diperkirakan membutuhkan 100 hingga 500 tahun hingga dapat terdekomposisi (terurai) dengan sempurna. Dengan demikian pemakaian plastik, baik plastik yang masih baru maupun sampah plastik haruslah menurut persyaratan yang berlaku agar tidak berbahaya terhadap kesehatan dan lingkungan. ${ }^{5}$

Kebanyakan plastik seperti Poly Vinyl Chloride (PVC), agar tidak bersifat kaku dan rapuh ditambahkan dengan suatu bahan pelembut. Beberapa contoh pelembut adalah Epoxidized Soybean Oil (ESBO), di (2-ethylhexyl) adipate (DEHA), dan Bifenil Poliklorin (PCB), Acetyl Tributyl Citrate (ATBC) dan di (2ethylhexyl) phthalate (DEHP). ${ }^{6}$

Untuk menghindari bahaya yang mungkin terjadi maka sebaiknya jika harus menggunakan plastik maka pakailah plastik yang terbuat dari polietilena dan polypropylene atau bahan alami (daun pisang misalnya). Plastik memiliki tekstur yang kuat dan tidak mudah terdegradasi oleh mikroorganisme tanah. Oleh karena itu seringkali kita membakarnya untuk menghindari pencemaran terhadap tanah dan air di lingkungan kita tetapi pembakarannya dan akan mengeluarkan asap toksik yang apabila dihirup dapat menyebabkan sperma menjadi tidak subur dan terjadi gangguan kesuburan. ${ }^{7}$

Satu lagi yang perlu diwaspadai dari penggunaan plastik dalam industri makanan adalah kontaminasi zat warna plastik dalam makanan. Sebagai contoh adalah penggunaan kantong plastik (kresek) untuk membungkus makanan seperti gorengan dan lain-lain. Menurut seorang ahli kimia, zat pewarna hitam ini kalau terkena panas (misalnya berasal dari gorengan), bisa terurai terdegradasi menjadi bentuk radikal, menyebabkan penyakit. Selain itu faktor yang menyebabkan rusaknya lingkungan hidup yang sampai saat ini adalah faktor pembuangan limbah sampah plastik. Kantong plastik telah menjadi sampah yang berbahaya dan sulit dikelola. Dibutuhkan waktu 1000 tahun agar plastik dapat terurai oleh tanah secara terdekomposisi atau terurai dengan sempurna. Ini adalah sebuah

5 Sutrisno Koswara, 2014, Bahaya di Balik Kemasan Plastik, Citra Aditya Bhakti, Bandung, hlm. 17-18.

Ibid.

7 Agus Haryono, 2008, Bahaya Kemasan Plastik Terhadap Kesehatan, Pradnya Paramita, Jakarta, hlm.18. 
waktu yang sangat lama. Saat terurai, partikel-partikel plastik akan mencemari tanah dan air tanah. ${ }^{8}$

Peringatan mengenai larangan untuk menggunakan kantong plastik hitam oleh Badan Pengawas Obat dan Makanan (BPOM) masih diindahkan oleh masyarakat. Banyak masyarakat yang menggunakan kantong plastik hitam dalam kehidupan sehari-hari tanpa mengetahui bahaya yang ditimbulkan dari penggunaan kantong plastik hitam tersebut. Husni Syawali dan Neni Sri Imaniyati menjelaskan bahwa rendahnya kesadaran dan pengetahuan konsumen, tidak mustahil dijadikan lahan bagi pelaku usaha dalam transaksi yang tidak mempunyai itikad baik dalam menjalankan usahanya, yaitu berprinsip mencari keuntungan yang sebesar-besarnya dengan memanfaatkan seefisien mungkin sumber daya yang ada. ${ }^{9}$ Dengan demikian, konsumen seolah dipaksa oleh pelaku usaha untuk terus menggunakan barang-barang dari plastik termasuk pemakaian kantong plastik hitam, yang tidak bisa terurai, yang pada akhirnya konsumenlah yang dikorbankan.

Informasi yang tidak dicantumkan mengenai cara pembuatan dan kandungan zat yang ada didalam kantong plastik hitam, membuat konsumen tidak mengetahui dengan pasti bahan-bahan yang digunakan dalam pembuatan kantong plastik hitam tersebut. Bahaya yang ditimbulkan dari penggunaan kantong plastik hitam memang tidak dapat dirasakan secara langsung namun dampaknya baru dapat dirasakan dalam jangka waktu yang lama. Meskipun demikian mengkonsumsi atau menggunakan kantong plastik dalam memenuhi kebutuhan sehari-hari dalam jangka waktu yang terlalu lama sangatlah berbahaya bagi kesehatan dan kehidupan konsumen pengguna kantong plastik kresek tersebut. Menurut Celina Tri Siwi Kristianti kenyamanan dan keamanan konsumen harus diperhatikan karena pada umumnya konsumen tidak mengetahui dari bahan apa suatu produk itu dibuat, bagaimana proses pembuatannya serta strategi pasar apa yang dijalankan untuk mendistribusikannya, maka diperlukan kaidah hukum yang dapat melindungi. ${ }^{10}$

8 Aqida Swamurti, 2009, Awas Bahaya Plastik Kresek Hitam, Remaja Rosdakarya, Bandung, hlm. 4.

9 Husni Syawali dan Heni Sri Imaniyati, 2000, Hukum Perlindungan Konsumen, Mandar Maju, Bandung, hlm. 36.

10 Celina Tri Siwi Kristiyanti, 2009, Hukum Perlindungan Konsumen, Sinar Grafika, Jakarta hlm.26. 
Produk hukum yang diciptakan pemerintah untuk mengatur mengenai perlindungan konsumen yaitu Undang-Undang Nomor 8 Tahun 1999 Tentang Perlindungan Konsumen (selanjutnya disebut Undang-Undang Perlindungan Konsumen). Undang-Undang Perlindungan Konsumen tersebut telah memberikan hak dan kewajiban pelaku usaha serta konsumen dalam rangka menciptakan pelaku usaha yang bertanggungjawab dan memberi kenyamanan serta keamanan pada konsumen dalam mengkonsumsi suatu produk barang atau jasa sebagai upaya dalam melakukan perlindungan terhadap konsumen, tetapi masih banyak masyarakat yang tidak mengetahui hak-haknya sebagai konsumen. Masyarakat tentunya harus mengetahui hak-haknya sebagai konsumen agar dapat terhindar dari berbagai bahaya yang ditimbulkan oleh produk-produk yang pembuatannya tidak memenuhi standar kelayakan dan beredar luas di masyarakat serta dikonsumsi oleh sebagian besar konsumen, salah satunya yaitu dalam mengkonsumsi kantong plastik hitam (plastik kresek) untuk memenuhi kebutuhan mereka.

Meskipun Undang-Undang Perlindungan Konsumen secara implisit sudah melarang penggunaan plastik mengingat akan bahayanya (das sollen), namun pada kenyataannya (das sein), baik pemerintah maupun konsumen sendiri seolah tidak peduli. Buktinya konsumen tidak ada yang protes saat diberikan bahan plastik, sebagai kemasan bagi makanan yang mereka beli. Pemerintah pun tidak melarang secara tegas penggunaan produk-produk plastik yang berbahaya bagi kesehatan konsumen, sehingga, pelaku usaha dapat dengan bebas menggunakan produk plastik yang berbahaya bagi kesehatan konsumennya.

Hingga saat ini, peneliti belum menemukan adanya Putusan Pengadilan yang mengadili pemakaian bahan plastik dikaitkan dengan bahaya plastik bagi kesehatan dan lingkungan. Hal ini disebabkan belum adanya aturan yang tegas mengenai bahaya dalam penggunaan bahan plastik. Selain itu, belum juga ditemukan adanya tuntutan ganti rugi sebagai akibat kerugian penggunaan bahan plastik.

Dengan demikian peran serta pemerintah, masyarakat dan perusahaan dalam pengelolaan lingkungan ini akan membuat kesehatan dan lingkungan terjaga dengan baik. Cara lain dalam rangka mengurangi keberadaan plastik dan sampah plastik adalah dengan cara mengurangi penggunaan barang-barang 
berbahan baku plastik atau menggantinya dengan barang yang non-plastik. Substitusi bahan plastik dengan bahan yang mudah diurai dan dihancurkan oleh lingkungan seperti bahan-bahan alami, misal: plastik dari jagung, kentang, dan lain-lain.

Berdasarkan latar belakang yang telah diuraikan di atas, permasalahan dalam penelitian ini dapat dirumuskan dalam bentuk research questions yaitu apakah aturan dalam Undang-Undang Nomor 18 Tahun 2008 tentang Pengelolaan Sampah belum dapat mencegah penggunaan plastik yang dapat menimbulkan sampah plastik yang berbahaya, mengapa belum ada peraturan perundang-undangan yang melarang penggunaan plastik yang membahayakan kesehatan dan lingkungan, serta bagaimana solusi belum diaturnya larangan penggunaan plastik yang membahayakan kesehatan dan lingkungan.

\section{B. METODE PENELITIAN}

Jenis penelitian ini menggunakan penelitian hukum normatif (normative legal research) merupakan penelitian yang dilakukan dengan cara mengkaji peraturan perundang-undangan yang berlaku atau diterapkan terhadap suatu permasalahan hukum tertentu. Penelitian normatif seringkali disebut dengan penelitian doktrinal, yaitu penelitian yang objek kajiannya adalah dokumen peraturan perundang-undangan dan bahan pustaka. ${ }^{11}$ Dalam peneltian normatif hukum dipandang identik dengan norma-norma tertulis, yang dibuat dan diundangkan oleh lembaga atau pejabat yang berwenang dan meninjau hukum sebagai suatu sistem normatif yang otonom, mandiri, tertutup dan terlepas dari kehidupan masyarakat nyata. ${ }^{12}$

Jenis pendekatan yang digunakan oleh peneliti adalah jenis pendekatan perundang-undangan (statute approach) dan pendekatan kasus (case approach), mengingat permasalahan yang diteliti dan dibahas dalam penelitian ini adalah mengenai aspek hukum bahaya plastik terhadap kesehatan dan lingkungan serta solusinya. Penelitian ini akan menjadikan pengelolaan sampah di Kabupaten Sleman sebagai model. 11 Peter Mahmud Marzuki, 2011, Penelitian Hukum, Kencana Prenida Media, Jakarta, hlm. 34.
12 lbid. 


\section{PEMBAHASAN}

1. Aturan dalam Undang-Undang Nomor 18 Tahun 2008 tentang Pengelolaan Sampah Terkait dengan Pencegahan Penggunaan Plastik yang Dapat Menimbulkan Sampah Plastik yang Berbahaya

Konsideran Undang-Undang Sampah menyebutkan bahwa pertambahan penduduk dan perubahan pola konsumsi masyarakat menimbulkan bertambahnya volume, jenis, dan karakteristik sampah yang semakin beragam. Pengelolaan sampah selama ini belum sesuai dengan metode dan teknik pengelolaan sampah yang berwawasan lingkungan sehingga menimbulkan dampak negatif terhadap kesehatan masyarakat dan lingkungan. Sampah telah menjadi permasalahan nasional sehingga pengelolaannya perlu dilakukan secara komprehensif dan terpadu dari hulu ke hilir agar memberikan manfaat secara ekonomi, sehat bagi masyarakat, dan aman bagi lingkungan, serta dapat mengubah perilaku masyarakat.

Undang-Undang Sampah tidak mengatur secara spesifik pengelolaan sampah plastik. Pasal 2 ayat (1) Undang-Undang Sampah mengkategorikan sampah menjadi 3 (tiga) yaitu sampah rumah tangga, sampah sejenis sampah rumah tangga dan sampah spesifik. Berdasarkan ketentuan Pasal 2 ayat (1) Undang-Undang Sampah ini maka dapat dikatakan bahwa Undang-Undang Sampah memang belum secara khusus mengatur adanya sampah plastik berikut bahaya yang ditimbulkannya.

Selanjutnya Pasal 2 ayat (4) Undang-Undang Sampah mengatur mengenai sampah spesifik yang terdiri dari:

a. sampah yang mengandung bahan berbahaya dan beracun;

b. sampah yang mengandung limbah bahan berbahaya dan beracun;

C. sampah yang timbul akibat bencana;

d. puing bongkaran bangunan;

e. sampah yang secara teknologi belum dapat diolah; dan/atau

f. sampah yang timbul secara tidak periodik.

Ketentuan Pasal 2 ayat (4) Undang-Undang Sampah tersebut diatas menimbulkan pertanyaan apakah sampah plastik termasuk sampah yang mengandung bahan berbahaya dan beracun ataukah sampah yang mengandung limbah bahan berbahaya dan beracun atau bisa juga sebagai 
sampah yang secara teknologi belum dapat diolah atau masih termasuk ketiga-tiganya. Mengenai sampah bahan berbahaya dan beracun (B3) Iswanto, Sudarmadji, Endang Tri Wahyuni mengartikan sampah yang memiliki karakteristik mudah meledak, mudah terbakar, reaktif, beracun, infeksius dan/atau korosif. ${ }^{13}$ Menurut Suratmin Utomo bahan berbahaya dan beracun (B3) didefinisikan sebagai bahan berbahaya dan/atau beracun yang karena sifatnya atau konsentrasinya baik secara langsung atau tidak langsung dapat mencemarkan lingkungan atau merusak lingkungan hidup, kesehatan hidup manusia serta, makhluk lain. B-3 dapat berupa bahan baku (alamiah), atau bahan olahan (produk), atau sisa dari suatu proses (limbah) yang bersumber dari kegiatan industri atau domestik (rumah tangga). ${ }^{14}$

Sementara itu menurut Dorota Klimecka-Tatar sampah yang mengandung bahan berbahaya dan beracun didefinisikan sebagai "Household solid waste containing hazardous and toxic materials such as batteries, electric light, electronics, pesticides, bleach, cleaner, paint, pressurized cans (aerosol), unused medicines, thermometers and syringes can threaten human and environment." ${ }^{15}$ (Terjemahan bebas: sampah rumah tangga yang mengandung bahan berbahaya dan beracun meliputi bateri, bohlam listrik, elektronik, pestisida, bahan pemutih, bahan pembersih, kaleng pestisida (aerosol), obat-obatan yang terpakai, yang membahayakan manusia dan lingkungan). Sedangkan menurut $\mathrm{S}$. Fairhust yang dimaksud dengan limbah B3 disini adalah setiap limbah yang mengandung bahan berbahaya dan/atau beracun yang karena sifat dan /atau konsentrasinya dan/atau jumlahnya, baik secara langsung maupun tidak langsung dapat merusak dan/atau mencemarkan lingkungan hidup dan/atau membahayakan. ${ }^{16}$

13 Iswanto, Sudarmadji, Endang Tri Wahyuni, 2016, Timbulan Sampah B3 Rumahtangga dan Potensi Dampak Kesehatan Lingkungan di Kabupaten Sleman, Yogyakarta (Generation of Household Hazardous Solid Waste and Potential Impacts on Environmental Health in Sleman Regency, Yogyakarta)", Jurnal Manusia dan Lingkungan, Vol. 23, No. 2, hlm. 180.

14 Suratmin Utomo, 2012, Bahan Berbahaya dan Beracun (B-3) dan Keberadaannya di dalam Limbah, Jurnal Konversi, Vol. 1, No. 1, hlm. 37-38.

15 Dorota Klimecka-Tatar, 2015, Safety Restriction in The Logistic of Dangerous and Toxic Subtances, Journal of Production Engineering Archives, Vol. 7, No. 2, hlm. 46.

16 S. Fairhust, 2003, Hazard and Risk Assessment of Industrial Chemicals in the Occupational Context in Europe: Some Current Issues, Journal of Food and Chemical Toxicology, Vol. 41, hlm. 26. 
Berdasarkan pengertian sampah yang mengandung bahan berbahaya dan beracun di atas, maka dapat disimpulkan apakah plastik termasuk ke dalam kategori bahan berbahaya dan beracun masih debatable. Terlebih lagi Pasal 2 ayat (5) Undang-Undang Sampah menyebutkan ketentuan lebih lanjut mengenai jenis sampah spesifik di luar ketentuan sebagaimana dimaksud pada ayat (4) diatur dengan peraturan menteri yang menyelenggarakan urusan pemerintahan di bidang lingkungan hidup. Dalam peraturan setingkat menteripun belum ditemukan yang mengatur mengenai sampah plastik.

Terkait dengan larangan penggunaan plastik yang dapat menimbulkan sampah plastik, Undang-Undang Sampah juga tidak mengaturnya. Pasal 29 ayat (1) huruf (c) dan huruf (d) hanya mengatur mengenai larangan bagi setiap orang untuk mencampur sampah dengan limbah berbahaya dan beracun dan mengelola sampah yang menyebabkan pencemaran dan/atau perusakan lingkungan. Ketentuan ini juga menimbulkan pertanyaan apakah sampah plastik plastik termasuk sampah yang dilarang oleh ketentuan Pasal 29 ayat (1) huruf (c) dan huruf (d) Undang-Undang Sampah tersebut. Larangan seperti yang diatur dalam Pasal 29 Undang-Undang Sampah tidak diikuti dengan adaanya sanksi baik sanksi administrasi maupun sanksi pidana. Hal ini menunjukkan bahwa larangan yang diatur dalam Pasal 29 UndangUndang Sampah tersebut menjadi tidak efektif.

Tidak adanya sampah plastik dalam Undang-Undang Sampah menyebabkan orang merasa bebas dan tidak takut untuk mengahasilkan dan membuang sampah plastik. Mereka beranggapan untuk menghasilkan dan membuang sampah plastik tidak ada larangannya apalagi sanksinya. Meskipun mereka tahu kalau sampah plastik itu berbahaya baik terhadap lingkungan maupun terhadap manusia, namun mereka tetap saja menghasilkan dan membuang sampah plastik disembarang tempat.

Berdasarkan pembahasan yang telah dikemukakan di atas maka dapat disimpulkan bahwa Undang-Undang Sampah tidak secara jelas mengatur mengenai sampah plastik dan larangan untuk menghasilkan sampah plastik yang berbahaya bagi manusia dan lingkungan.

2. Belum Adanya Peraturan Perundang-Undangan yang Melarang Penggunaan Plastik yang Membahayakan Kesehatan dan Lingkungan 
Sampai saat ini belum ada peraturan perundang-undangan yang melarang penggunaan plastik yang membahayakan bagi kesehatan manusia dan lingkungan. Larangan penggunaan plastik baru sebatas plastik sebagai kemasan bahan pangan diatur dalam Peraturan Kepala Badan Pengawas Obat dan Makanan Nomor : Hk 00.05.55.6497 tentang Bahan Kemasan Pangan (selanjutnya disebut Peraturan Kepala Badan POM tentang Bahan Kemasan Plastik). Pasal 1 angka 1 Peraturan Kepala Badan POM tentang Bahan Kemasan Plastik menyebutkan bahwa kemasan pangan adalah bahan yang digunakan untuk mewadahi dan/atau membungkus pangan baik yang bersentuhan langsung dengan pangan maupun tidak. Sementara itu Pasal 1 angka 3 mendefinisikan plastik sebagai senyawa makromolekul organik yang diperoleh dengan cara polimerisasi, polikondensasi, poliadisi, atau proses serupa lainnya dari monomer atau oligomer atau dengan perubahan kimiawi makromolekul alami.

Pasal 3 ayat (1) Peraturan Kepala Badan POM tentang Bahan Kemasan Plastik mengatur Bahan yang dilarang digunakan sebagai bahan kemasan pangan adalah bahan tambahan seperti yang tercantum dalam Lampiran 1. Plastik yang tidak dapat didaur ulang termasuk salah satu dalam Lampiran 1 Peraturan Kepala Badan POM tentang Bahan Kemasan Plastik. Oleh karena itu plastik yang tidak dapat didaur ulang dilarang untuk digunakan sebagai bahan kemasan pangan. Selanjutnya Pasal 3 ayat (2) Peraturan Kepala Badan POM tentang Bahan Kemasan Plastik menyebutkan bahan yang diizinkan sebagaimana dimaksud dalam pasal 2 huruf $b$ terdiri dari bahan dasar dan bahan tambahan. Pasal 3 ayat (3) Peraturan Kepala Badan POM tentang Bahan Kemasan Plastik mengatur bahan dasar sebagaimana dimaksud pada ayat (2) seperti tercantum dalam Lampiran 2A. Plastik yang dapat diatur ulang termasuk salah satu dalam Lampiran 2A. Oleh karena itu, plastik yang dapat didaur ulang dapat digunakan sebagai bahan kemasan pangan setelah mendapat izin. Izin yang dimaksudkan disini berasal dari Kepala Badan POM. Hal ini diatur dalam Pasal 10 ayat (1) Peraturan Kepala Badan POM tentang Bahan Kemasan Plastik yang mengatur dilarang menggunakan kemasan pangan dari bahan plastik daur ulang sebelum diperiksa keamanannya dan mendapat persetujuan dari Kepala Badan POM. 
Sanksi bagi yang melanggar larangan tersebut di atas diatur dalam Pasal 11 ayat (1) Peraturan Kepala Badan POM tentang Bahan Kemasan Plastik yang menyebutkan pelanggaran terhadap peraturan ini dikenai sanksi administratif dan atau sanksi pidana sesuai dengan ketentuan peraturan perundang-undangan yang berlaku. Sanksi administratif sebagaimana dimaksud pada ayat (1) berupa:

a. peringatan tertulis;

b. larangan mengedarkan untuk sementara waktu;

c. perintah menarik produk dari peredaran;

d. pemusnahan jika terbukti menimbulkan risiko terhadap kesehatan;

e. pencabutan persetujuan pendaftaran produk pangan. (Pasal 11 ayat (2)

Peraturan Kepala Badan POM tentang Bahan Kemasan Plastik)

Tidak dapat dipungkiri bahwa saat ini plastik merupakan kemasan pangan yang banyak digunakan oleh pelaku usaha untuk membungkus makanan dan minuman yang diproduksinya. Hal ini karena plastik memiliki sifat-sifat unggulan seperti: kuat tetapi ringan, tidak berkarat, bersifat termoplastis, yaitu dapat direkat menggunakan panas, serta dapat diberi label atau cetakan dengan berbagai kreasi.

Permasalahan-permasalahan yang sering kali dihadapi oleh masyarakat berkaitan dengan penggunaan produk plastik sebagai kemasan pangan adalah sebagai berikut.

a. Penggunaan bahan yang dilarang digunakan maupun penggunaan bahan dasar yang digunakan tidak sesuai dengan tipe pangan dan kondisi penggunaan tertentu sebagaimana yang telah ditetapkan dalam Peraturan Kepala BPOM tentang Bahan Kemasan Pangan. Beberapa pelaku usaha juga kerap tidak mencantumkan keterangan mengenai jenis plastik yang digunakannya sebagai pembungkus makanan dan/atau minuman yang diproduksinya, padahal pencantuman keterangan mengenai jenis plastik ini sangat penting artinya karena konsumen dapat mengetahui apakah plastik yang digunakan sebagai pembungkus makanan dan/atau minuman yang dibelinya berbahaya bagi kesehatannya atau tidak.

Banyak pelaku usaha makanan dan minuman, terutama yang tidak terdaftar di BPOM yang menggunakan bahan tambahan bagi plastik yang dilarang 
digunakan maupun penggunaan bahan dasar yang digunakan tidak sesuai dengan tipe pangan dan kondisi penggunaan tertentu sebagaimana yang telah ditetapkan dalam Peraturan Kepala BPOM tentang Bahan Kemasan Pangan. Sebagai contohnya adalah para pelaku usaha rumah makan. Banyak pelaku usaha rumah makan maupun para pedagang makanan dan/atau minuman di pinggir jalan yang menggunakan styrofoam sebagai bahan pembungkus/wadah bagi makanan dan minuman yang dijualnya. Hal ini karena styrofoam relatif murah harganya, berwarna putih, sehingga menimbulkan kesan bersih dalam penggunaannya, dan juga memiliki kemampuan untuk menahan suhu panas atau dingin yang baik. Pada kenyataannya styrofoam ini berbahaya bagi kesehatan manusia. Styrofoam jadi berbahaya karena terbuat dari butiran-butiran styrene, yang diproses dengan menggunakan benzena. ${ }^{17}$ Benzena ini sendiri di dalam Lampiran 1 Peraturan Kepala BPOM tentang Bahan Kemasan Pangan, termasuk bahan tambahan yang dilarang digunakan sebagai kemasan pangan untuk bahan dasar plastik.

Jika styrofoam digunakan sebagai wadah/kemasan bagi makanan dan/atau minuman, bahan kimia berbahaya yang terkandung dalam styrofoam akan berpindah ke makanan dan/atau minuman yang dikemasnya. Perpindahannya akan semakin cepat jika kadar lemak (fat) dalam suatu makanan atau minuman makin tinggi. Selain itu, minuman yang mengandung alkohol atau asam, seperti lemon tea, juga dapat mempercepat laju perpindahan. ${ }^{18}$ Jadi, penggunaan styrofoam sebagai kemasan pangan sendiri telah melanggar ketentuan Peraturan Kepala BPOM tentang Bahan Kemasan Pangan.

b. Tidak dicantumkannya simbol dan kode segitiga serta keterangan dari jenis plastik pada produk plastik yang digunakan oleh pelaku usaha sebagai kemasan pembungkus pangan yang diproduksinya. Selama ini, tidak ada kewajiban bagi pelaku usaha untuk mencantumkan simbol dan kode segitiga serta keterangan mengenai plastik pada produk plastik yang digunakannya. Namun arti simbol dan kode segitiga serta keterangan dari

17 Ibnu Susanto, 2014, Bahan Kimia Berbahaya dan Keselamatan Kesehatan Kerja Bidang Kimia, Balai Pustaka, Jakarta, hlm. 36.

18 Ibid. 
jenis plastik ini sangatlah penting bagi konsumen. Dengan melihat dan membaca simbol dan kode segitiga serta keterangan dari jenis plastik yang digunakan oleh pelaku usaha sebagai kemasan pangan, konsumen dapat menentukan mana plastik berbahaya yang dapat mencemari pangan yang dikemasnya dan mana plastik yang aman bagi pangan. Tidak mungkin bagi konsumen untuk melakukan uji laboratorium pada setiap plastik pembungkus pangan yang dibelinya, hanya untuk menentukan apakah plastik tersebut berbahaya atau tidak. ${ }^{19}$

Pelaku usaha yang menggunakan kantong plastik sebagai bahan kemasan pangan dapat dikatakan telah melakukan pelanggaran hukum terhadap UUPK UU Pangan dan PP tentang Keamanan, Mutu dan Gizi Pangan. Masyarakat sebagai konsumen dalam berbagai segi merupakan pihak yang lemah kedudukannya bila dibandingkan dengan pelaku usaha. Oleh karena itu diperlukan suatu aturan yang dapat melindungi kepentingan konsumen agar tidak dirugikan atau diperlakukan sewenang-wenang oleh pelaku usaha.

\section{Solusi Belum Diaturnya Larangan Penggunaan Plastik yang} Membahayakan Kesehatan dan Lingkungan

Sampah yang terus bertambah di Kabupaten Sleman dan tidak dikelola dengan baik dapat menimbulkan masalah baik pada pemerintah, sosial masyarakat, kesehatan, dan lingkungan. Sampah yang dibuang oleh masyarakat di Kabupaten Sleman setiap harinya berasal dari kegiatan pertanian, pasar, rumah tangga, hiburan dan industri. Salah satu bentuk sampah adalah sampah dometik yang merupakan salah satu kegiatan rumah tangga yang menyisakan limbah domestik atau sampah masyarakat. Bertambahnya sampah domestik sejalan dengan perkembangan pembangunan fisik, dan pertambahan peningkatan sarana dan prasarana yang memadai. Akibat dari pencemaran tersebut keseimbangan lingkungan terganggu, misalnya terjangkitnya penyakit menular.

Kebiasaan membuang sampah sembarangan dilakukan hampir di semua kalangan masyarakat di Kabupaten Sleman, tidak hanya warga miskin, bahkan mereka yang berpendidikan tinggi juga melakukannya. Ini sangat

19 Ibid. 
menyedihkan karena minimnya pengetahuan tentang sampah dan dampaknya. Perilaku buruk ini semakin menjadi karena minimnya sarana kebersihan yang mudah dijangkau oleh masyarakat di tempat umum. Data berikut menunjukkan timbulan sampah rumah tangga yang termasuk sampah berbahaya sebagai berikut:

Tabel 2. Timbulan Sampah Rumah Tangga di Kabupaten Sleman pada Tahun 2017

\begin{tabular}{lrrrr}
\hline \multicolumn{1}{c}{ Jenis Sampah Rumah Tangga } & \multicolumn{2}{c}{ Jumlah } & \multicolumn{2}{c}{ Berat } \\
& Item & \multicolumn{1}{c}{$\%$} & \multicolumn{1}{c}{ gram } & \multicolumn{1}{c}{$\%$} \\
\hline Baterai bekas & 122 & 24,65 & 5938 & 16,71 \\
Lampu listrik bekas & 140 & 21,48 & 6425 & 18,08 \\
Elektronik bekas & 49 & 8,63 & 8854 & 24,91 \\
Bekas kemasan cat & 35 & 6,16 & 2278 & 6,41 \\
Bekas kemasan pestisida & 22 & 3,87 & 2169 & 6,10 \\
Sisa dan kemasan obat/medis & 66 & 11,62 & 2415 & 6,79 \\
Bekas kemasan gas dan bahan bakar & 39 & 6,87 & 1882 & 5,29 \\
Kemasan produk perawatan diri dan kecantikan & 65 & 11,44 & 3894 & 10,96 \\
Kemasan produk pemeliharaan rumah & 30 & 5,28 & 1689 & 4,75 \\
Jumlah & 568 & 100 & 35544 & 100,00 \\
Rata-rata Timbulan & 0,04 & & 2,44 & \\
& item/ & g/org/ & \\
& org/ & hari & \\
\hline
\end{tabular}

Sumber: Dinas Kebersihan dan Pertamanan Kabupaten Sleman.

Dari tabel di atas, dapat ditunjukkan timbulan sampah yang termasuk bahan berbahaya di Kabupaten Sleman 0,04 item/org/hari atau 2,44 gram/org/hari. Meskipun kecil, tetapi resiko yang ditimbulkan sampah berbahaya ini tidak boleh diabaikan. Kondisi ini semakin buruk, mengingat di Kabupaten Sleman tidak tersedia Tempat Pembuangan Sampah (TPS) yang memadai. Akibatnya banyak bermunculan TPS ilegal yang apabila tidak dikelola dengan baik dapat menimbulkan pencemaran lingkungan. Jumlah keberadaan TPS ilegal ini dapat dilihat di Kecamatan Godean, Kabupaten Sleman yang ditunjukkan pada tabel berikut.

Tabel 3. TPS Legal dan TPS Ilegal di Kecamatan Godean, Kabupaten Sleman, Daerah Istimewa Yogyakarta Tahun 2017

\begin{tabular}{|c|c|c|c|c|}
\hline \multirow{2}{*}{ No } & \multirow{2}{*}{ Nama Desa } & \multicolumn{2}{|c|}{ Jumlah } & \multirow{2}{*}{ Keterangan } \\
\hline & & Legal & Ilegal & \\
\hline 1 & Sidoarum & - & 4 & $\begin{array}{l}\text { Sampah organik dan anorganik } \\
\text { Lokasi : } 7 \mathrm{~m} \text { dari jalan raya, dekat parit, di pinggir } \\
\text { jalan (dekat sawah), di tepi jalan }\end{array}$ \\
\hline 2 & Sidomoyo & 2 & 6 & $\begin{array}{l}\text { Sampah organik dan anorganik } \\
\text { Lokasi legal : tepi jalan di dekat persawahan, } \\
\text { Lokasi ilegal : lima di tepi jalan, satu di samping } \\
\text { jembatan }\end{array}$ \\
\hline
\end{tabular}




\begin{tabular}{|c|c|c|c|c|}
\hline 3 & Sidokarto & - & 4 & $\begin{array}{l}\text { Sampah organik dan anorganik } \\
\text { Lokasi : dua tepi jalan di dekat persawahan, satu di } \\
\text { samping jembatan, satu di dekat pasar }\end{array}$ \\
\hline 4 & Sidomulyo & - & 2 & $\begin{array}{l}\text { Sampah organik dan anorganik } \\
\text { Lokasi :satu di tepi jalan utama, satu di lahan kosong }\end{array}$ \\
\hline 5 & Sidoagung & - & 19 & $\begin{array}{l}\text { Sampah organik dan anorganik } \\
\text { Lokasi : satu di perkebunan, satu di pemukiman, } 17 \\
\text { lokasi di tepi jalan raya }\end{array}$ \\
\hline 6 & Sidoluhur & - & 9 & $\begin{array}{l}\text { Sampah organik dan anorganik, } \\
\text { Lokasi : tepi jalan }\end{array}$ \\
\hline 7 & Sidorejo & 1 & 1 & $\begin{array}{l}\text { Sampah organik dan anorganik } \\
\text { Lokasi Legal : di tepi jalan } \\
\text { Lokasi llegal : di pinggir sungai }\end{array}$ \\
\hline & Total & 3 & 45 & \\
\hline
\end{tabular}

Data pada tabel di atas menunjukkan bahwa dari ketujuh desa didapatkan hasil bahwa Desa Sidoagung memiliki TPS ilegal terbanyak sejumlah 19. Desa Sidorejo memiliki 1 TPS Ilegal dan 1 TPS Legal, Desa Sidomulyo memiliki 2 TPS Ilegal, Desa Sidokarto memiliki 4 TPS Ilegal, dan Desa Sidoarum memiliki 4 TPS Ilegal, Desa Sidomoyo memiliki 6 TPS Ilegal dan 2 TPS Legal. Dari ketujuh desa tersebut, Desa Sidorejo memiliki jumlah TPS llegal dengan jumlah paling sedikit dibandingkan dengan desa-desa yang lainnya. Pengolahan sampah di TPS ilegal dilakukan dengan dibakar. Pengolahan sampah di TPS legal dilakukan oleh Dinas Pekerjaan Umum yang bekerjasama dengan Dinas Lingkungan Hidup.

Dari ketujuh desa tersebut didapatkan hasil Desa Sidoagung yang memiliki TPS ilegal terbanyak dengan jumlah 19. Dari ketujuh desa tersebut Desa Sidorejo memiliki jumlah TPS ilegal dengan jumlah paling sedikit dibandingkan dengan desa-desa yang lainnya. Semua desa/kelurahan di Godean memiliki TPS ilegal dan hanya 2 desa yang memiliki TPS legal, yaitu Desa Sidomoyo dan Desa Sidorejo. Hal ini kemungkinan karena keterbatasan pemerintah dalam menyediakan sarana prasarana pengelolaan sampah, termasuk TPS, sampai ke lingkup desa.

Tempat pembuangan sampah ilegal seharusnya tidak dijadikan sebagai tempat pembuangan sampah dimana lokasi-lokasi tersebut bukan merupakan lahan yang memiliki izin resmi untuk dijadikan sebagai tempat pembuangan seperti sungai, selokan, pinggiran sawah, dan dekat jalan raya. Selain dapat merugikan pemilik lahan hal tersebut juga dapat mengganggu nilai estetika lingkungan yang berada disekitarnya.

TPS legal memang sudah disediakan sebagai tempat pembuangan sampah oleh pemerintah. Lahan yang digunakan merupakan lahan yang 
memang telah disediakan oleh masyarakat atau dinas yang terkait. Tempat pembuangan sampah ini telah memiliki izin yang sudah disahkan dari pihak pemerintah yang nantinya sampah yang ada akan diangkut ke tempat pembuangan akhir (TPA).

Mengingat hingga saat ini belum ada peraturan perundang-undangan yang mengatur larangan penggunaan plastik, maka sebagai solusinya masyarakat diharapkan dapat berpartisipasi untuk menangani sampah plastik yang berbahaya terhadap kesehatan dan lingkungan. Untuk mengelola sampah plastik ini, Desa Sidoagung, Kecamatan Godean, Kabupaten Sleman sedang merintis program Gojek Sampah Plastik. Gojek Sampah Plastik (disingkat GOTIK) yang diharapkan menjadi solusi terbaik dalam mengurangi sampah plastik mengingat masyarakat belum paham tentang pentingnya penanganan sampah plastik dan harus dilakukan sistem menjemput langsung dan membelinya agar masyarakat menjadi termotivasi karena selama ini masyarakat tidak paham yang dulu sampah plastik dibuang sekarang menjadi uang. Adapun alur pelayanan GOTIK dapat dilihat pada gambar berikut:

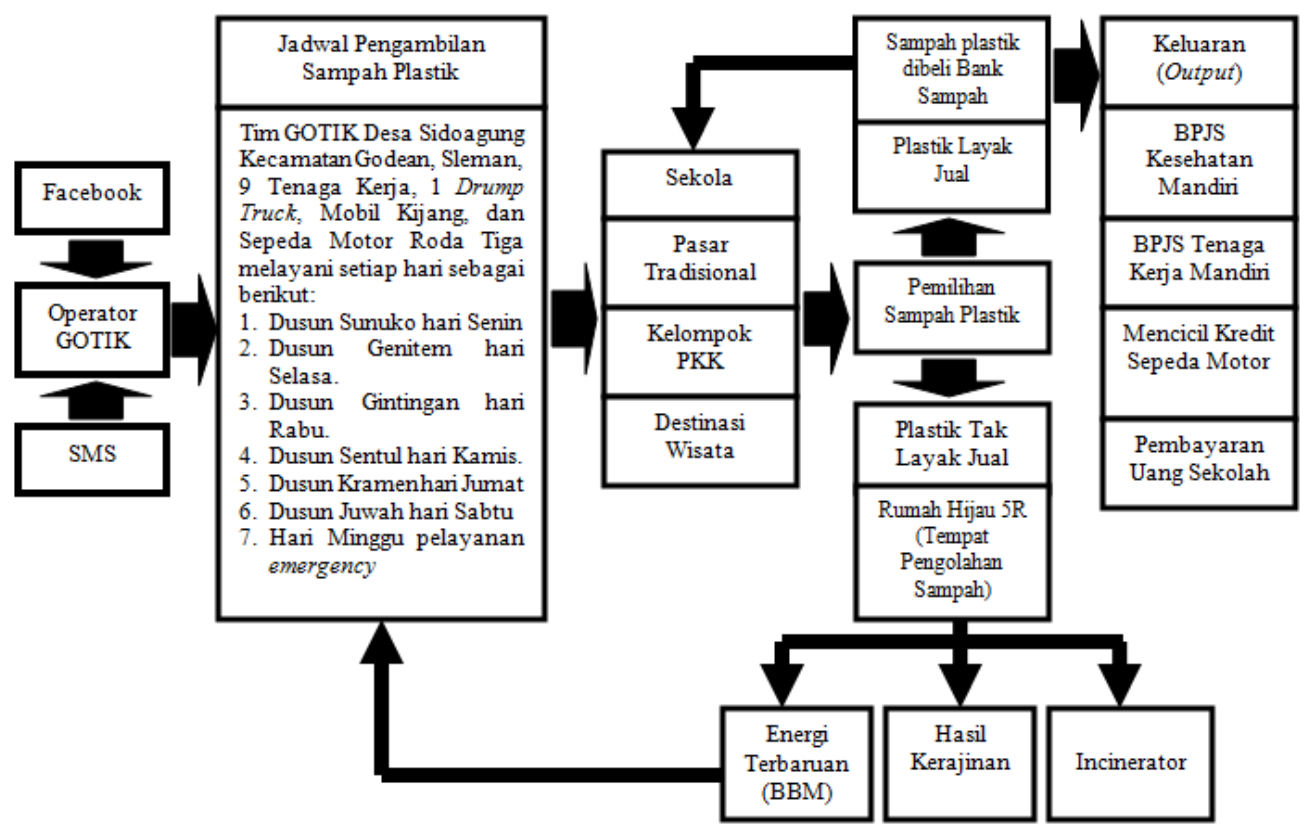

Gambar 1. Alur Pelayanan Tim GOTIK di Desa Sidoagung, Kecamatan Godean, Kabupaten Sleman

Adapun strategi pelaksanaan GOTIK tersebut meliputi sebagai berikut.

a. SMS Hotline Service 
Masyarakat bisa langsung menjual sampah plastik melalui sms yang ditujukan kepada Tim GOTIK Desa Sidoagung, Kecamatan Godean, Kabupaten Sleman, dengan syarat sudah mencantumkan alamat dan lokasi yang jelas, dimana sampah tersebut bisa diambil serta mencantumkan jumlah sampah yang akan dijual berapa kilo. Hal ini harus dilakukan agar Tim GOTIK Desa Sidoagung, Kecamatan Godean, Kabupaten Sleman bisa membawa sarana prasarana dan nominal uang yang jelas ke tempat lokasi. Selain itu syarat yang lain adalah pelayanan hanya dilakukan di wilayah Desa Sidoagung, Kecamatan Godean, Kabupaten Sleman.

\section{b. Free Door To Door Service}

Untuk masyarakat Desa Sidoagung, Kecamatan Godean, Kabupaten Sleman yang langsung ingin menjual sampah plastik tidak perlu pusing, karena Tim GOTIK Desa Sidoagung, Kecamatan Godean, Kabupaten Sleman melakukan pelayanan pembelian sampah langsung datang ke rumah dan gratis untuk biaya jemputnya. Adapun syaratnya yaitu lokasi yang diberikan harus jelas dan hanya dilayani wilayah Desa Sidoagung, Kecamatan Godean, Kabupaten Sleman, selain itu jalan menuju lokasi agar bisa dilalui dengan kendaraan Tim GOTIK Desa Sidoagung, Kecamatan Godean, Kabupaten Sleman

c. Quick Service

Tim GOTIK Desa Sidoagung, Kecamatan Godean, Kabupaten Sleman berusaha mengambil sampah plastik yang dijual dari masyarakat dengan layanan yang super cepat, jangan sampai sampah plastik yang akan diambil terjadi penumpukan yang banyak di rumah, asalkan sudah sesuai dengan jadwal pelayanan Tim GOTIK Desa Sidoagung, Kecamatan Godean, Kabupaten Sleman yaitu: hari Senin melayani wilayah RT 01, Selasan RT 02, Rabu RT 03, Kamis RT 04, Jumat RT 05, Sabtu RT 06 dan hari Minggu adalah untuk pelayanan emergency.

d. Pemberian Cash

Tim GOTIK Desa Sidoagung, Kecamatan Godean, Kabupaten Sleman akan memberikan bantuan cash kepada masyarakat langsung ditimbang dan dibayar dengan harga yang sudah ditetapkan menurut jenis sampah plastik Rp. 500/kg, dan steroform/gabus Rp. 200kg dengan catatan semua 
sampah yang diambil harus kering tidak basah. Khusus kelompok PKK menggunakan pola reguler, yaitu sekarang diambil dan seminggu baru dibayar sesuai jadwal layanan.

e. Dapat hadiah langsung bagi pengumpul sampah plastik terbanyak dan tanpa diundi setiap bulan

f. Pelayanan dengan sistem RT

Pelayanan pengambilan sampah plastik oleh Tim GOTIK Desa Sidoagung, Kecamatan Godean, Kabupaten Sleman dilakukan dengan sistem cepat setiap hari kepada masyarakat. Pelayanan tersebut dirancang secara permanen yaitu mempergunakan pola wilayah yang harus dilakukan pelayanan 1 hari tuntas untuk $1 \mathrm{RT}$ dengan rincian sebagai berikut.

1) Pelayanan untuk RT 01 pada hari Senin.

2) Pelayanan untuk RT 02 pada hari Selasa.

3) Pelayanan untuk RT 03 pada hari Rabu.

4) Pelayanan untuk RT 04 pada hari Kamis.

5) Pelayanan untuk RT 05 pada hari Jumat.

6) Pelayanan Kecamatan Kuta Petang pada hari Sabtu.

7) Pada hari Minggu pelayanan emergency.

Sistem pengelolaan sampah plastik yang baik akan mengurangi kerusakan lingkungan. Karena sampah plastik dapat merugikan kesehatan, keamanan, pencemaxan dan merupakan sesuatu yang tidak dipergunakan lagi dan harus dibuang, maka sampah plastik harus dikelola dengan sebaikbaiknya sedemikian rupa sehingga hal-hal negatif bagi kehidupan tidak sampai terjadi. Agar sampah plastik dapat dikelola dengan baik maka sebelumnya harus diketahui atau diperhatikan faktor-faktor yang mempengaruhinya baik dari segi kualitas maupun kuantitasnya.

Selanjutnya, di Kabupaten Sleman juga dilakukan upaya pengelolaan sampah rumah tangga dengan melibatkan partisipasi masyarakat. Dalam pelaksanaannya, pengelolaan tersebut dilaksanakan oleh semua pemegang peran atau stakeholder baik pemerintah sesuai tugas masing-masing, masyarakat serta pelaku pembangunan lainnya dengan memperhatikan keterpaduan perencanaan dan kebijakan yang ditentukan. Oleh karena itu maka perencanaan yang melibatkan partisipasi masyarakat selaku 
stakeholder menjadi penting. Hal tersebut didasari pertimbangan bahwa dengan perencanaan yang melibatkan partisipasi masyarakat, maka program pengelolaan sampah akan menjadi harmonis, berdaya guna dan berhasil guna sekaligus wahana untuk mewujudkan peningkatan kemampuan masyarakat dalam pelaksanaan perencanaan dari bawah bottom up planning.

\section{PENUTUP}

Undang-Undang Nomor 18 Tahun 2008 tentang Pengelolaan Sampah tidak secara jelas mengatur mengenai sampah plastik dan larangan untuk menghasilkan sampah plastik. Ketidakjelasan pengaturan sampah plastik ini dapat ditunjukkan bahwa Undang-Undang Nomor 18 Tahun 2008 tersebut hanya mengkategorikan sampah menjadi 3 (tiga) yaitu sampah rumah tangga, sampah sejenis sampah rumah tangga dan sampah spesifik (Pasal 2 ayat (1)). Penjelasan mengenai sampah spesifik itu tidak memasukkan sampah plastik sebagai sampah spesifik (Pasal 2 ayat (1)). Oleh karena itu UndangUndang Nomor 18 Tahun 2008 tentang Pengelolaan Sampah belum dapat mencegah penggunaan plastik yang dapat menimbulkan sampah plastik yang berbahaya bagi manusia dan lingkungan.

Sampai saat ini belum ada peraturan perundang-undangan yang melarang penggunaan plastik yang membahayakan bagi kesehatan manusia dan lingkungan. Larangan penggunaan plastik baru sebatas plastik sebagai kemasan bahan pangan diatur dalam Peraturan Kepala Badan Pengawas Obat dan Makanan Nomor : Hk 00.05.55.6497 tentang Bahan Kemasan Pangan. Mengingat plastik yang tidak bisa terurai membahayakan bagi lingkungan hidup, maka secara eksplisit Undang-Undang Nomor 32 Tahun 2009 tentang Perlindungan dan Pengelolaan Lingkungan Hidup melarang pembuangan barang-barang termasuk sampah plastik yang dapat merusak lingkungan hidup. Sementara itu, plastik jika didaur ulang berbahaya bagi manusia sehingga pemerintah dan DPR selaku pembuat undang-undang harus segera membuat peraturan singkat undang-undang untuk mencegah penggunaan plastik yang sampah plastiknya berbahaya bagi kesehatan dan lingkungan. 
Solusi belum diaturnya larangan penggunaan plastik yang membahayakan kesehatan dan lingkungan maka sampah plastik bisa digunakan sebagai bahan untuk membuat kerajinan seperti aneka jenis tas, dompet, topi tempat koran, map, dan sebagainya seperti yang telah dilakukan oleh masyarakat Desa Sukunan, Kabupaten Sleman selama ini.

Terkait dengan hal-hal tersebut, Pemerintah bersama-sama DPR selaku pembuat undang-undang disarankan untuk segera membuat undang-undang yang melarang penggunaan plastik yang nyata-nyata membahayakan kesehatan dan lingkungan dan juga membuat undang-undang yang mengatur pengelolaan sampah plastik agar tidak membahayakan kesehatan dan lingkungan. Selain itu, pemerintah daerah disarankan untuk terus memotivasi masyarakat untuk berpartisipasi dalam pengelolaan sampah plastik agar masyarakat selalu yakin dan taat untuk ikut mengelola sampah yang ada. Kemauan masyarakat ini akan muncul dengan bantuan dorongan dari pemerintah daerah berupa kemudahan-kemudahan dalam pengadaan sarana dan prasarana dalam menunjang kebersihan. Masyarakat disarankan untuk mengurangi penggunaan bahan-bahan dari plastik secara bertahap seperti misalnya tidak lagi menggunakan styrofoam dan kantong plastik sebagai pembungkus makanan serta menggantinya dengan daun atau bahan-bahan alami lainnya yang tidak membahayakan bagi manusia dan lingkungan.

\section{DAFTAR PUSTAKA}

\section{Buku}

Bappeda Kabupaten Sleman, 2016, Profil Sanitasi Kabupaten Sleman, 2015. Pemerintah Kabupaten Sleman, Sleman.

Haryono, Agus, 2008, Bahaya Kemasan Plastik Terhadap Kesehatan, Pradnya Paramita, Jakarta.

Koswara, Sutrisno, 2014, Bahaya di Balik Kemasan Plastik, Citra Aditya Bhakti, Bandung.

Kristiyanti, Celina Tri Siwi, 2009, Hukum Perlindungan Konsumen, Sinar Grafika, Jakarta.

Marzuki, Peter Mahmud, 2011, Penelitian Hukum, Kencana Prenida Media, Jakarta. 
Rahmadi, Takdir, 2014, Hukum Lingkungan di Indonesia, Rajawali Pers, Jakarta.

Susanto, Ibnu, 2014, Bahan Kimia Berbahaya dan Keselamatan Kesehatan Kerja Bidang Kimia, Balai Pustaka, Jakarta.

Swamurti, Aqida, 2009, Awas Bahaya Plastik Kresek Hitam, Remaja Rosdakarya, Bandung.

Syawali, Husni dan Imaniyati, Heni Sri, 2000, Hukum Perlindungan Konsumen, Mandar Maju, Bandung.

Peraturan Perundang-Undangan

Undang-Undang Dasar Negara Republik Indonesia Tahun 1945.

Undang-Undang Nomor 8 Tahun 1999 tentang Perlindungan Konsumen.

Undang-Undang Nomor 18 Tahun 2008 tentang Pengelolaan Sampah.

Undang-Undang Nomor 32 Tahun 2009 tentang Perlindungan dan Pengelolaan Lingkungan Hidup.

Peraturan Pemerintah Nomor 81 Tahun 2012 tentang Pengelolaan Sampah Rumah Tangga dan Sampah Sejenis Sampah Rumah Tangga.

Peraturan Menteri Dalam Negeri (Permendagri) Nomor 33 Tahun 2010 tentang Pedoman Pengelolaan Sampah.

Peraturan Daerah Kabupaten Sleman Nomor 4 Tahun 2015 tentang Pengelolaan Sampah Rumah Tangga dan Sampah Sejenis Sampah Rumah Tangga.

\section{Sumber Lain}

Fairhust, S., 2003, Hazard and Risk Assessment of Industrial Chemicals in the Occupational Context in Europe: Some Current Issues, Journal of Food and Chemical Toxicology, Vol. 41.

Iswanto, Sudarmadji, Wahyuni, Endang Tri, 2016, Timbulan Sampah B3 Rumahtangga dan Potensi Dampak Kesehatan Lingkungan di Kabupaten Sleman, Yogyakarta (Generation of Household Hazardous Solid Waste and Potential Impacts on Environmental Health in Sleman Regency, Yogyakarta)", Jurnal Manusia dan Lingkungan, Vol. 23, No. 2.

Karuniastuti, Nurhenu, Bahaya Plastik terhadap Kesehatan dan Lingkungan, Jurnal Forum Teknologi, Vol. 03, No. 1. Dalam http://pusdiklatmigas.esdm.go.id/file/t2- Bahaya Plastik --- Nurhenu K.pdf.

Klimecka-Tatar, Dorota, 2015, Safety Restriction in The Logistic of Dangerous and toxic Subtances, Journal of Production Engineering Archives, Vol. 7, No. 2. 
Purwaningrum, Pramiati, 2016, Upaya Mengurangi Timbulan Sampah Plastik di Lingkungan, JTL Vol. 8 No. 2.

Puteri, Irawati, et.al., 2018, Penerapan Plastic Deposit Refund System sebagai Instrumen Penanggulangan Pencemaran Limbah Plastik di Wilayah Perairan Indonesia, Jurnal Hukum Lingkungan Indonesia, Vol. 4, No. 2.

Umar, Al dan Budi, Santoso, 2011, Penegakan Hukum Lingkungan di Indonesia, Wacana Hukum, Vol. IX, No. 2.

Utomo, Suratmin, 2012, Bahan Berbahaya dan Beracun (B-3) dan Keberadaannya di dalam Limbah, Jurnal Konversi, Vol. 1, No. 1. 